\title{
Mapping Land Used After Bricks Mining Area at Potorono Village Banguntapan Yogyakarta
}

\author{
Susila Herlambang*, Purwono Budi Santosa \\ Department of Soil Science, University Pembangunan Nasional Veteran Yogyakarta Indonesia, Yogyakarta, Indonesia \\ Email address: \\ susilaherlambang@upnyk.ac.id (S. Herlambang) \\ ${ }^{*}$ Corresponding author
}

To cite this article:

Susila Herlambang, Purwono Budi Santosa. Mapping Land Used After Bricks Mining Area at Potorono Village Banguntapan Yogyakarta. International Journal of Applied Agricultural Sciences. Vol. 4, No. 1, 2018, pp. 21-27. doi: 10.11648/j.ijaas.20180401.14

Received: November 13, 2017; Accepted: December 24, 2017; Published: January 19, 2018

\begin{abstract}
The degradation on the soil after bricks mining was limited land used to agriculture plant in fields. The out put this research to know land used after mining in the various depths after bricks mining. The mapping was land used after bricks mining in the six villages mining at Potorono Banguntapan District of Yogyakarta in the 2016. The method of this research was used survey techniques and over lapping map land use. Mapping base was used satellite imagery map to determine the boundaries of operations, and then use the map was used various soil deeper in mining. The map of the plant is determining on the land use after the land was reclamation lands. The result of this research is mapping irrigated lands, settlements, gardens, and field moor at several debts after bricks mining. The pasca bricks mining will be restrict land use of agricultural. At mining on the depth about $100 \mathrm{~cm}$ was grown by paddy soil in land, while the mining of more than $200 \mathrm{~cm}$, the wetland is unsuitable by paddy soil. The limited alternative of agriculture plants was determined by the level of decline fertility and organic matter in soil, add bulk density and sand content in the soil. In the former bricks mining can be planted with paddy soil is an area with good irrigation requirements with a production under 7 tones per hectare. While in the mining above $200 \mathrm{~cm}$ and nothing irrigation, the farmers will be grown crops with irrigation depends on the rain. The conclusion on the research is content of organic matter in the mining was important by nutrient storage soil. The amelioration to marginal soil was soil structure repaired by organic matter for water and nutrient storage. The nutrient was sufficient to determine on reclamation to growth of plants after the mining for sustainability agriculture. On the brick mining was allowed soil take at top soils, after mining it must be done as soon as possible for reclamation land towards sustainability agriculture.
\end{abstract}

Keywords: Amelioration, Bricks Mining, Land Use, Organic Matter, Sustainability Agriculture

\section{Introduction}

The rice product was declined per year for effect an imbalance to needs of rural food sufficiency. Potorono district has area about 410.52 hectare, an irrigated land about 174 hectare and non-irrigated 2 hectare. The agricultural area has decreased of each year due to the land use for settlement and mine. The objective of research was maped post mining bricks.. The land use was changed paddy soil to brick industry mining carried out by 6 village in Potorono, the change function land use was added to take home pay for family income in the short term. The mining was done in the village Potorono is brick mine, the soil was taken from top soil until subsoil by mine. Mining was carried out continuously will cause damage to land, soil losse on the top soil until sub soil was taken effect in soil degradation on quality became production of crops would be lower (Antonious et al., 2014). Mining on productive land leads to lower crop production, declining soil nutrients and organic matter, losse clay content, and increased bulk density (Costantini \& Lorenzetti, 2013). Damage on the soil was problem in the agriculture, especially in fertility, physic and chemical properties of soil. The mine allotment brick industry with taken at various depths on the soil was different land use in post mining. In the mine Potorono village take soil in the depth on 100,200, and $300 \mathrm{~cm}$, loss of top soil and irrigation of field availability both effect of different in the land use and management plants. Mapping of the post tilling 
in brick mining to give information the mining of wide area, losse of soil in the depth, and land use. Mapping in the field productive land on the post tiling bricks was known lang use and total production in agriculture. While information in the map overlapping was used completely spatial planning agriculture and the policy of rural development based on sustainable agriculture without damaging the environment (Johnson et al., 2010; Koarashi et al., 2012; Laborde \& others, 2011; Lenssen et al., 2015; Olson et al., 2013). The mine was taken in soil about $>300 \mathrm{~cm}$ or deeper, its limited to alternative agricultural cultivation and required hight costs to improve soil physical and soil chemical. The amelioration material was requirements to improve of soil damage and repaired of nutrient soil. The amelioration matter of livestock manure is a source of soil organic matter to improve soil from heavy structure to repaired be came freable structure, source of nutrient and to increase cation exchangeable capasity. To improvement of soil that have been damaged by the addition of continuously ameliorant to be came sustainable agriculture. The establishment of sustainable agriculture is not a short time but need a long time and cost a lot to go eco-farming system in agriculture.

\section{Material and Methods}

The map of research was bricks mining do in the village Potorono Banguntapan Yogyakarta in March until December 2016. Location of bricks mining sampling was made at six village at different of the depth levels of mining. The soil sample was used survey techniques and the methods was used purposive to directly locations determine and soil sampling was conducted at various depths in the post mining brick. In each mining depth analysis in the laboratory i.e. Bulk density with ring method, soil texture by pipetting method, and organic matter using the method of Walkley and Black, with formulation $100 / 58 \mathrm{x} \% \mathrm{C}$ in the soil. The map process was made with GIS ArcView Extensions version 3.3 by using the registry and the transform to tool and spatial extensions an alias. The technique of mechanical register map using extensions register and transform tool. The first step must be done is to enable this extension and extensions JPEG or JFIF image support by selecting the file menu extensions, then the view will appear sub menu and transform registers and maps will be registered in the form Format *JPG or * TIFF. Next on the menu view selected by submenu registers and transform. After that be found dialogue and transform to known of determine sample area or point coordinates. These coordinates are usually already present on the map in such earth RBI map. The step of repetitions performed at least at four different places to find the RMS smallest error. If you have not found the RMS smallest error, to repeat again until indicate value found of the smallest RMS error.
After getting the value of the smallest RMS error to click write world file. This is creating a new file which is the file that bind JPEG file earlier so that its position in accordance with the actual surface. Once the file was saved, the theme JPEG going out and called again. After this process is done redialing, the map is already registered in the position coordinates, then close the dialog box register and transform to pass over lapping between the mine site map, depth of mining map and land use map. Outcomes research in the form of a map of the mine site at different depths in the soil which in overlapping with a map of land use after the land reclamation post mining is done by farmers. The distribution of the organic matter can be used as one indicator potential of soil fertility to determine was used agriculture of sustainable.

\section{Results and Discussions}

The results of mapping land post mining brick shows the productive land has decreased quality of the soil on different depths at mining. The Potorono village to be six located bricks mining on the site with depth on the soil 100-300 cm (Figure 1), the all of which are traditional miners performed with tools simple for the industry on brick mine of family scale. Mining productive land can not be avoided by traditional miners due to economic factors with the brick-making family economic conditions becoming better and at lower risk. The productive land at Potorono has paddy soil with irrigation system about $42.39 \%$ and not irrigation about $0.49 \%$. Mining on productive land resulting decline in soil quality and reduce the extent of the production of paddy soil. Deterioration of soil quality post mining will affect the commodity alternative be limited for cultivated of plants (Antonious et al., 2014; Johnson et al., 2010; Osman, 2014). Land use changes due to the presence of bricks mining are not organized by their traditional mining resulted in the total rice production decreased, so it need the mapping of the mining area.

The damage post mining to physical and chemical properties is a major factor as limiting the fertility of the soil (Antonious et al., 2014; Barto et al., 2010; Basso et al., 2010; Du Pont et al., 2010; González-Peñaloza et al., 2012). Soil organic matter content has decreased below the sufficiency threshold after mining $<1 \%$ (Table 1 ). Mining by taking soil in the top soil and sub soil $100-300 \mathrm{~cm}$, to give effect to limited alternative cultivation on agricultural land use. In the post mining a depth in $100 \mathrm{~cm}$ with good system irrigation can be planted by paddy soil while the poor irrigation the farmer had planted mostly zea mays, chili and peanuts. The low of organic matter and soil compaction lead to make limitations on the cultivation of agricultural land. 


\section{Map of Pasca Bricks Mining Distribution at Potorono Village, Banguntapan, Bantul, Yogyakarta}

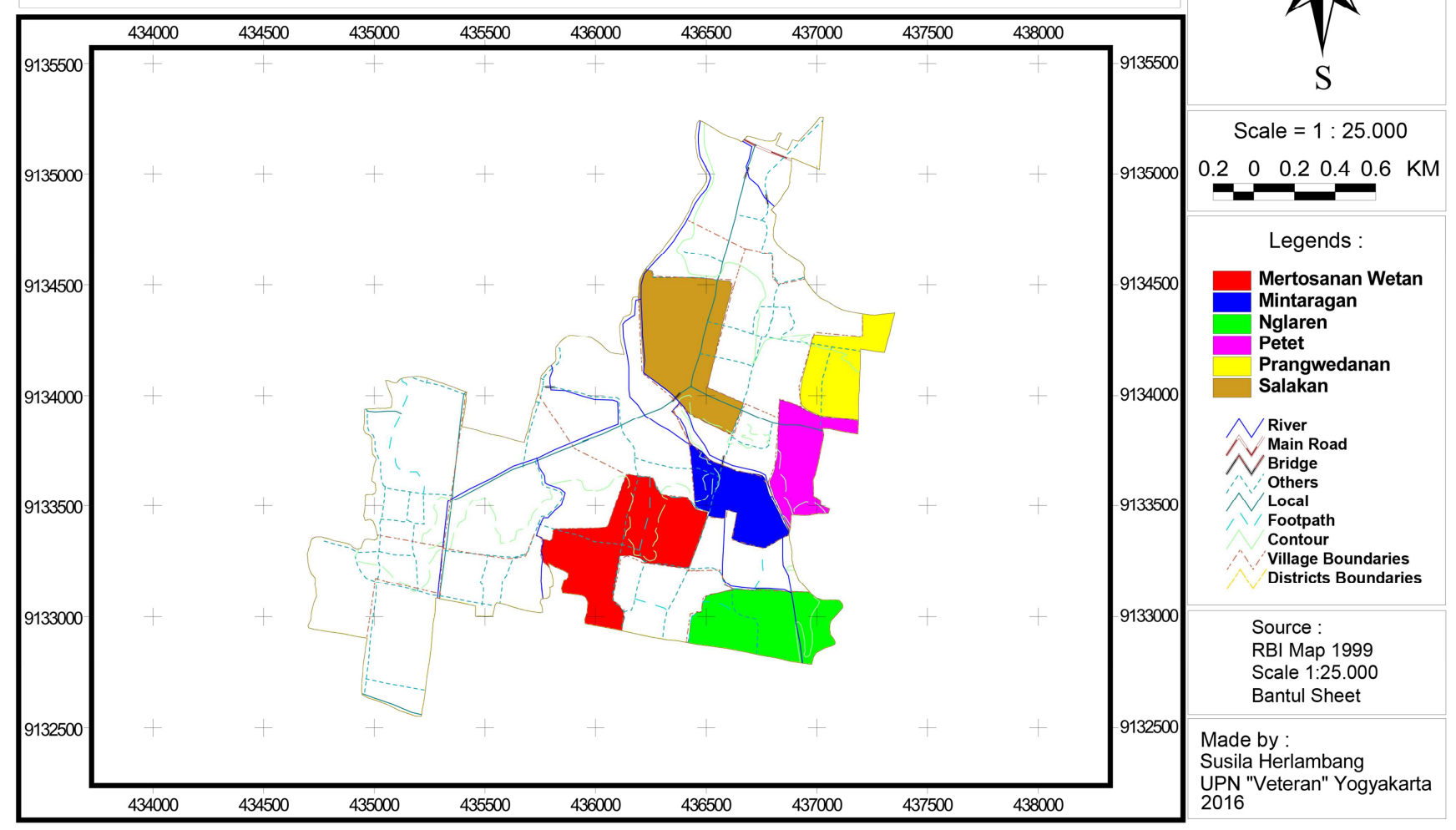

Figure 1. Distribution of briks tilling village at Potorono village Banguntapan Yogyakarta.

Table 1. Distribution of briks tilling areas at Potorono village Banguntapan Yogyakarta.

\begin{tabular}{|c|c|c|c|c|c|c|c|c|}
\hline \multirow{3}{*}{ District of village } & \multirow{3}{*}{ Land use } & \multicolumn{6}{|l|}{ Distribution of } & \multirow{3}{*}{ Large areas $\left(\mathrm{m}^{2}\right)$} \\
\hline & & \multirow{2}{*}{ Depth tilling (cm) } & \multirow{2}{*}{ Organic matter (\%) } & \multirow{2}{*}{ Bulk Dencity $\left(\mathrm{g} / \mathrm{cm}^{3}\right)$} & \multicolumn{3}{|c|}{ Fraction (\%) } & \\
\hline & & & & & Clay & Silt & Sand & \\
\hline Mintaragan & paddy soil & 120 & 0.79 & 1.26 & 7.6 & 31.7 & 60.8 & 125525.43 \\
\hline Nglaren & peanuts & 300 & 0.78 & 1.4 & 0.4 & 13.8 & 40.64 & 204752.23 \\
\hline Prangwedanan & zea mays & 210 & 0.29 & 1.48 & 1.0 & 12.8 & 86.2 & 131528.68 \\
\hline Petet & zea mays & 200 & 0.62 & 1.42 & 3.0 & 15.3 & 81.7 & 125722.68 \\
\hline
\end{tabular}

The land use post mining for agriculture do not require plants suitable high nutrient response in dry land like chilli, zea mays, and beans. The source of organic matter on the top soil, loss of organic matter by the top soil of mined was resulting in poor nutrient made in agricultural land. On depth of mining about $100 \mathrm{~cm}$, the farmer can land used for paddy soil cultivated due mertosanan Wetan village area cause system irrigation very good. The irrigation is key to cultivating rice although the adequacy of soil organic matter is very small at $1.08 \%$ (table 1 ). In fact the farmer was improvement organic manure in large quantities. The addition of manure will continually help to repaired for physical and chemical properties of soil. The post mining was caused land degradation, especially the occurrence of soil compaction, mining at a depth about $>100 \mathrm{~cm}$ to showing bulk density $>1.4$ $\mathrm{g} / \mathrm{cm}^{3}$. The compacting be come aeration is very low and the soil will be impede rooting development of soil. The soil improvement through amelioration was required and must be done for repaired damage soil structure effect post mining (Jagadamma \& Lal, 2010). Amelioration with organic manure, chicken, duck and sheep will be use in the support source of nutrients and soil structure improvement (Grewal et al., 2011; Johnson et al., 2010; Olson et al., 2013; Virto, Barré et al., 2012; Wick et al., 2013). The depth of mining cant stopped at the all locations of mine at Potorono village, while not found the hard pan on thickness and sand fraction dominates. The layer hard and sand to much cannot used made bricks industry. Distribution of taken soil in the top soil post mining at Potorono village a depth of $0-100 \mathrm{~cm}$ in the village i.e. Mertosanan Wetan, mining to a depth of 101-200 $\mathrm{cm}$ i.e. Mintaragan, Salakan and Petet, and depth 201-300 cm i.e. Prangwedanan and Nglaren village (Figure 2). On the mine of depth about $100 \mathrm{~cm}$ in productive land its still possible to cultivate for land use pady soil, although the amount of 
organic matter $1.08 \%$. The deficiency of organic matter can be added to the $\mathrm{C}$ source a amelioration by providing livestock manure from farmers. Besides that Mertosanan wetan village have good irrigation for agriculture thus supporting land use for plants to pady soil. On the mining about $>300 \mathrm{~cm}$ making the losse top soil more deeply because the boundary layer in the form of hardpan not been found and the composition of the sand fraction is still dominating compared to the another fraction are dust and clay, but they can be used for industrial materials brick mining.

\section{Map of Depth After Mining in the Pasca Bricks Mining at Potorono Village, Banguntapan, Bantul, Yogyakarta}
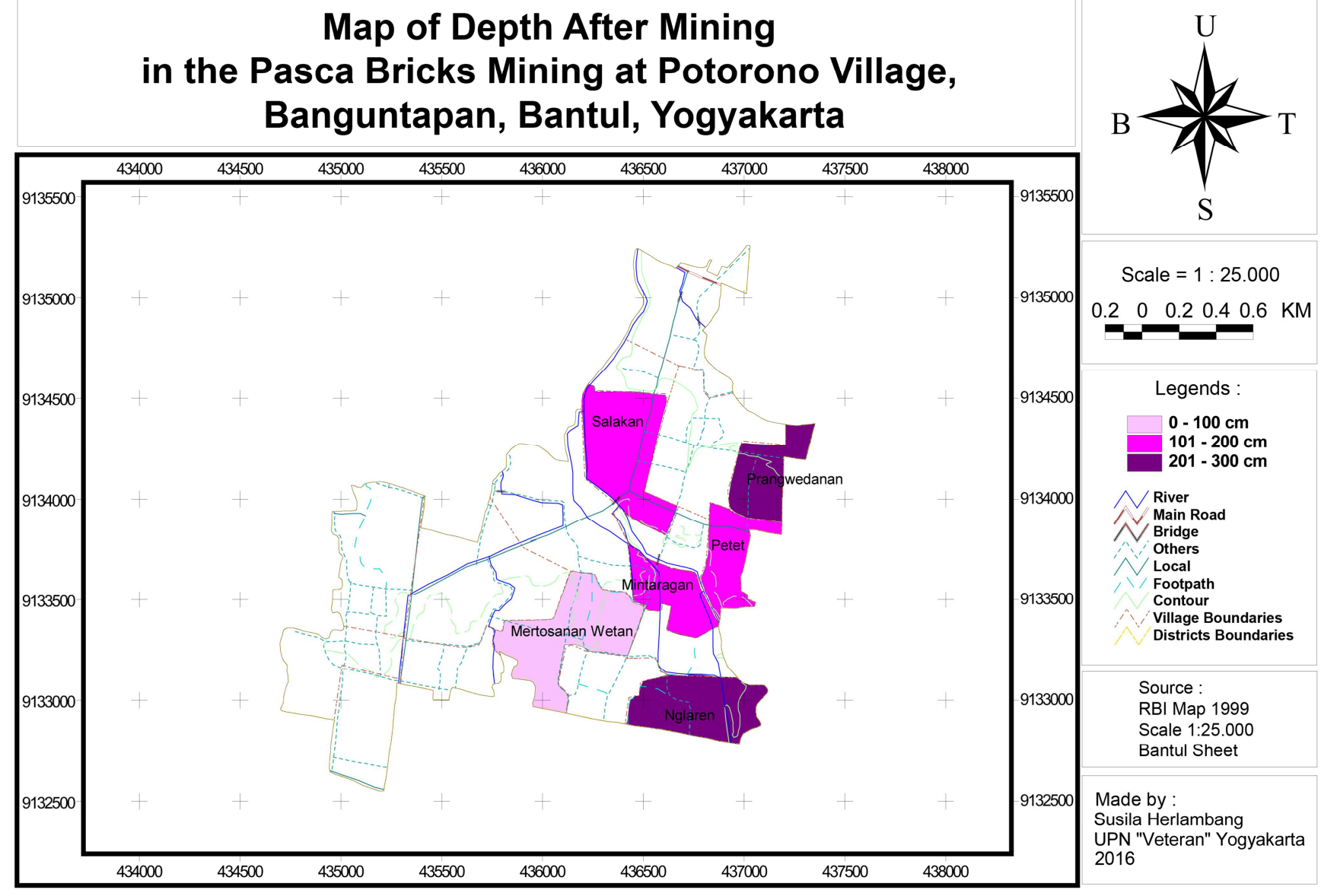

Figure 2. Mapping depht of soil pacsa briks tilling at Potorono village Banguntapan Yogyakarta.

Mapping land use and soil depth by overlapping a compilation to determine the distribution of soil depth level role with limited post mining land use in accordance with the actuality on the fields. Most of the land area was irrigation system at Potorono village, showed the potential of the region is the source of rice (Table 2). Almost length area at Potorono fields are irrigated showing potential land use to paddy soil. Their mining for bricks making change of land use agriculture paddy soil with briks industry local. Intake of top soil until subsoil at mine in the six village are various on the depth who depending on the depth for potential material on bricks. The miners will take the soil as deep as possible regardless of the level of damage to the land for economic purposes (Johnson et al., 2010; Lenssen et al., 2015; Volchko et al., 2013). Mapping the depth of mining of various thicknesses to differentiate depths i.e. $<100 \mathrm{~cm}, 101-200 \mathrm{~cm}$ and $>300 \mathrm{~cm}$ effect on land use. The mining bricks is mostly done in paddy fields than on dry land, this is due to the composition of the soil texture is more in accordance with the technique of making bricks and it supported drains very easily. The miners did not rule mining is done in the dry land after the brick-making material thinning so as to make more widespread land damage in quality of soil and loss of productive land. The mining bricks do most in Mertosanan Wetan village about 19.18 hectare and Nglaren village about 12.69 hectare with both on the depth mine different (Table 2). On the Nglaren village was deeper than Mertosanan Wetan. The physical properties of the soil will affect the depth of deeper take in the soil, the layer has a smaller bulk density allow more the mining deeper to compared on soil that has a bulk density greater. Often clay content not be a main problem on the bricks because the miners would bring additional clay materials from outsider. At Potorono mine show that the bricks mine Nglaren village has a clay content about $0.2 \%$, they done deeper with another location bricks mine. 
Table 2. Distribution of depht tilling and land use areas at Potorono village Banguntapan Yogyakarta.

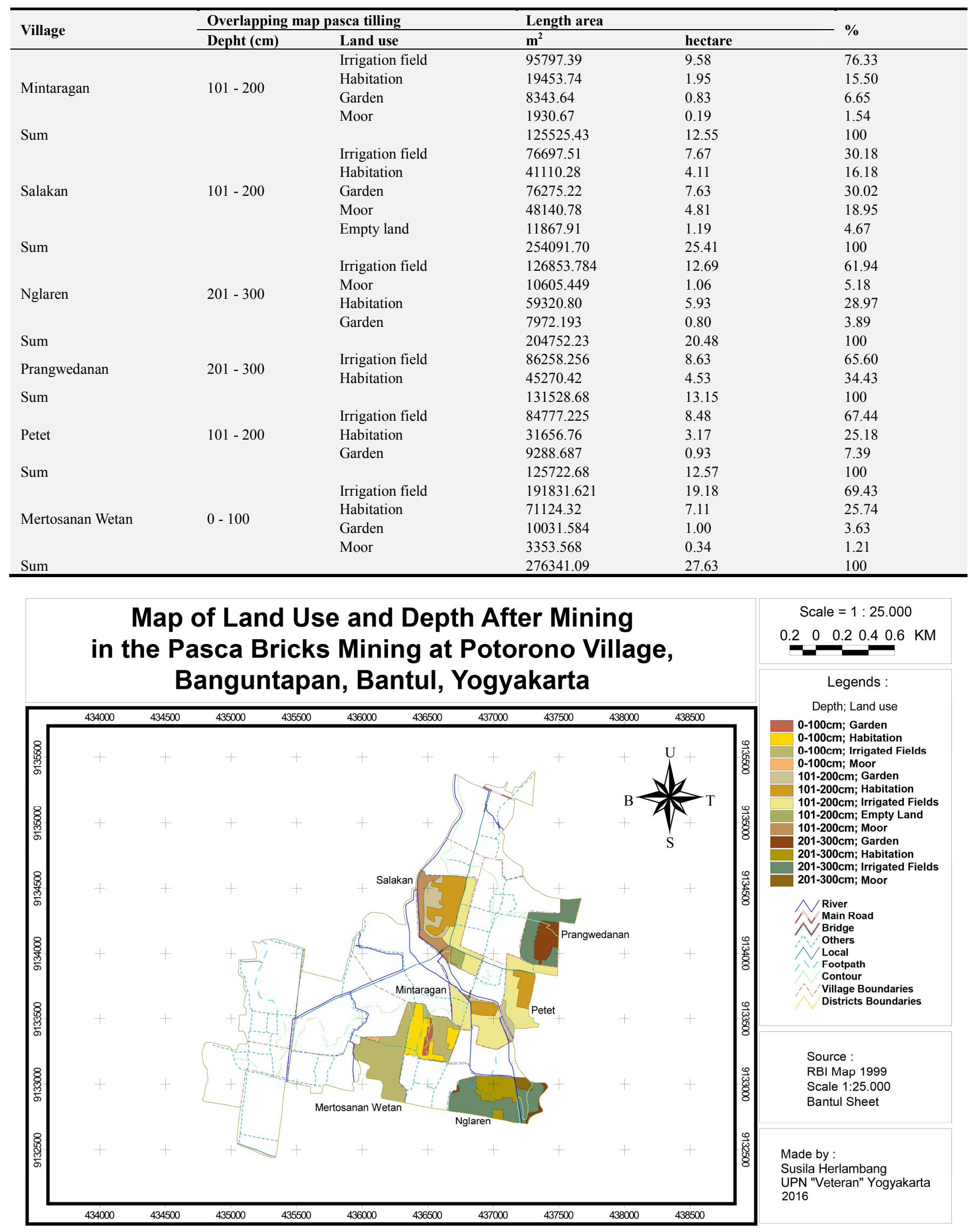

Figure 3. Mapping land use on the depth of soil pacsa briks tilling at Potorono village Banguntapan Yogyakarta. 
The effect of post mining will be damage both physical and chemical soil, degradation of soil quality be came development of the limitations of cultivation. The activity miners will be stopped after found hard layers conditions, its can not be used for the manufacture of bricks with bulk Dencity $>1.4 \mathrm{~g} / \mathrm{cm}^{3}$. The Farmers in the productive land will use rice cultivation with input high nutrient from the amelioration and has similar good water, while in the area post mining nothing irrigation condition is insufficient for paddy soil then the farmers land use cultivator with dryland plants i.e chili, zea mays and beans (Antonious et al., 2014; He et al., 2012; Johnson et al., 2010; Kato et al., 2012; Wick et al., 2013). To According farmers post mining was used any ameliorant source organic manure not so good production in the field. The paddy soil was declined production in field or on dry land, soil productivity is declining despite the ameliorant average showed decline $>50 \%$ of the results before mining. Production of rice before mining about $>7$ tonnes per hectare and pacsa briks tilling have 3-5 tons per hectar (direct interview, 2016). On reality the results showed decline on the product so the farmer interested to rent out their land for make bricks, because the anticipation economic is quickly without the need of long time result product, low risk and losse energy in the use of land.

\section{Conclusions}

The post mining bricks on the productive land was given impact declining soil quality, damage soil physic and chemic characteristic increasing the bulk density of the soil, decline organic matter in top soil and lower cation exchangeable capacity. The depth of mine will be correlated with result and ameliorant so limited of crops, the mining depth on $100 \mathrm{~cm}$ still can be used cultivated paddy soil with requirement good irrigation, while mining at a depth on 200-300 cm using dryland plants. Recommendation: the mining area brick industry can not be stopped, so necessary to the arrangement of bricks in the mining area of productive land by regulating how land is allowed drawn in the top soil. The capture of land allowed to be based on taking into account the availability of organic material and the thickness of the soil layer.

\section{Acknowledgements}

Thank to LPPM Universitas pembangunan Nasional Veteran Yogyakarta University, supported through applied research grants on 2015/20016.

\section{References}

[1] Antonious, G. F., Turley, E. T., \& Hill, R. R. (2014). Impact of soil amendments on metribuzin and DCPA half-lives and mobility into agricultural run off water. Journal of Environmental Science and Health, Part B, 49 (5), 313-323.

[2] Barto, E. K., Alt, F., Oelmann, Y., Wilcke, W., \& Rillig, M. C. (2010). Contributions of biotic and abiotic factors to soil aggregation across a land use gradient. Soil Biology and Biochemistry, 42 (12), 2316-2324.

[3] Basso, B., Amato, M., Bitella, G., Rossi, R., Kravchenko, A., Sartori, L., Gomes, J. (2010). Two-dimensional spatial and temporal variation of soil physical properties in tillage systems using electrical resistivity tomography. Agronomy Journal, 102 (2), 440-449.

[4] Costantini, E. A., \& Lorenzetti, R. (2013). Soil degradation processes in the Italian agricultural and forest ecosystems. Italian Journal of Agronomy, 8 (4), 28.

[5] DuPont, S. T., Culman, S. W., Ferris, H., Buckley, D. H., \& Glover, J. D. (2010). No-tillage conversion of harvested perennial grassland to annual cropland reduces root biomass, decreases active carbon stocks, and impacts soil biota. Agriculture, Ecosystems \& Environment, 137 (1), 25-32.

[6] González-Peñaloza, F. A., Cerdà, A., Zavala, L. M., Jordán, A., Giménez-Morera, A., \& Arcenegui, V. (2012). Do conservative agriculture practices increase soil water repellency? A case study in citrus-cropped soils. Soil and Tillage Research, 124, 233-239.

[7] Grewal, S. S., Cheng, Z., Masih, S., Wolboldt, M., Huda, N., Knight, A., \& Grewal, P. S. (2011). An assessment of soil nematode food webs and nutrient pools in community gardens and vacant lots in two post-industrial American cities. Urban Ecosystems, 14 (2), 181-194.

[8] He, N., Zhang, Y., Dai, J., Han, X., Baoyin, T., \& Yu, G. (2012). Land-use impact on soil carbon and nitrogen sequestration in typical steppe ecosystems, Inner Mongolia. Journal of Geographical Sciences, 22 (5), 859-873.

[9] Jagadamma, S., \& Lal, R. (2010). Distribution of organic carbon in physical fractions of soils as affected by agricultural management. Biology and Fertility of Soils, 46 (6), 543-554.

[10] Johnson, M., Isakov, V., Touma, J. S., Mukerjee, S., \& Özkaynak, H. (2010). Evaluation of land-use regression models used to predict air quality concentrations in an urban area. Atmospheric Environment, 44 (30), 3660-3668.

[11] Kato, H., Onda, Y., \& Teramage, M. (2012). Depth distribution of $137 \mathrm{Cs}, 134 \mathrm{Cs}$, and $131 \mathrm{I}$ in soil profile after Fukushima Dai-ichi Nuclear Power Plant accident. Journal of Environmental Radioactivity, 111, 59-64.

[12] Koarashi, J., Atarashi-Andoh, M., Matsunaga, T., Sato, T., Nagao, S., \& Nagai, H. (2012). Factors affecting vertical distribution of Fukushima accident-derived radiocesium in soil under different land-use conditions. Science of the Total Environment, 431, 392-401.

[13] Laborde, D., \& others. (2011). Assessing the land use change consequences of European biofuel policies. International Food Policy Institute (IFPRI). Retrieved from http://re.indiaenvironmentportal.org.in/files/file/biofuelsreport ec2011.pdf.

[14] Lenssen, A. W., Sainju, U. M., Jabro, J. D., Allen, B. L., \& Evans, R. G. (2015). Management and tillage influence barley forage productivity and water use in dryland cropping systems. Agronomy Journal, 107 (2), 551-557.

[15] Olson, N. C., Gulliver, J. S., Nieber, J. L., \& Kayhanian, M. (2013). Remediation to improve infiltration into compact soils. Journal of Environmental Management, 117, 85-95. 
[16] Osman, K. T. (2014). Physical Deterioration of Soil. In Soil Degradation, Conservation and Remediation (pp. 45-67). Springer. Retrieved from http://link.springer.com/10.1007/978-94-007-7590-9_2

[17] Virto, I., Barré, P., Burlot, A., \& Chenu, C. (2012). Carbon input differences as the main factor explaining the variability in soil organic $\mathrm{C}$ storage in no-tilled compared to inversion tilled agrosystems. Biogeochemistry, 108 (1-3), 17-26.
[18] Volchko, Y., Norrman, J., Bergknut, M., Rosén, L., \& Söderqvist, T. (2013). Incorporating the soil function concept into sustainability appraisal of remediation alternatives. Journal of Environmental Management, 129, 367-376.

[19] Wick, A. F., Daniels, W. L., Orndorff, Z. W., \& Alley, M. M. (2013). Organic matter accumulation post-mineral sands mining. Soil Use and Management, 29 (3), 354-364. 